\author{
MARTIN KOPECKÝ \\ ORCID: 0000-0001-5958-7027 \\ University of West Bohemia, Faculty of Law \\ (Západočeská univerzita v Plzni, Fakulta právnická) \\ kopeckym@ksp.zcu.cz \\ JANA BALOUNOVÁ \\ ORCID: 0000-0002-3170-8904 \\ University of West Bohemia, Faculty of Law \\ (Západočeská univerzita v Plzni, Fakulta právnická) \\ janabal@ksp.zcu.cz
}

\title{
Self-Government Activities of Professional Chambers - Legislation and Application (with a Focus on the Conditions of the Czech Republic)
}

\begin{abstract}
The article "Self-Government Activities of Professional Chambers" is focused on the exercising of self-government by professional chambers as public corporations, especially on its legislation and application in conditions of Czech Republic. The article presents professional chambers in the Czech Republic, which are based on compulsory membership. The article also deals with the issue of compensation when there is damage caused by professional chambers. Finally, attention is paid also to statutory regulations as a form of abstract acts published by professional chambers.
\end{abstract}

Keywords: self-government, professional chambers, compensation, statutory regulations.

\section{Self-Government in the Czech Republic}

Self-government offers the public the opportunity to participate in the administration of public affairs which are ensured by the state and for which the state is responsible. Self-government can be defined, on the one hand, in the political 
context as the participation of citizens - non-professionals - in public administration, for instance, in advisory bodies or inspection bodies of public institutions elected by the parliament; and, on the other hand, in the legal context in which execution of a part of public administration is assigned to a subject independent of the state. Such a self-government subject is not subordinated to the state bodies; for the entities performing self-government activities (their bodies), the state bodies execute legal oversight as to whether they act in compliance with the laws and other legal regulations, i.e., within an established legal framework. In the legal sense of the word, self-government is a legal society of people forming a corporation, which is a public corporation. The concept of self-governance has received a lot of attention in literature; of the historical sources which are also mentioned by the contemporary Czech authors in their citations, one can refer to, for instance, the authors of the first half of the 20th century, namely Jiři Hoetzel, ${ }^{1}$ or Adolf Merkl, professor in Vienna and proponent of the normative school, whose book translated from German to Czech was used at the Faculty of Law in Brno in the interwar period as a textbook of administrative law. ${ }^{2}$

The basis of public self-government lies in self-government founded on a territorial basis and executed by local units - municipalities or possibly higher self-governmental units bearing different names; in the present Czech model, they are called regions. Territorial self-government, as a rule, has constitutional grounds, and as it concerns virtually the whole population, and as its organization and functioning require coordination with the establishment of institutions ensuring the administration of the state, it has tasks divided between the state and the self-governmental units so as to be able to deal with the public matters of the inhabitants in the various spheres of public administration. But self-government does not only concern the territorial self-government. Self-government institutions are also being established for the involved persons to be able to administer by themselves or to take greater part in the administration of matters which are also regulated by the public law but concern the interests of predominantly selected professions, economic branches, or social needs. The establishment of corporations which address such matters in a self-governmental way and which are identified in summary as corporations of so-called self-governance of interest groups ${ }^{3}$ is conditioned by an act of the state, most frequently a law, but also expects initiative from those persons who want to administer such matters in the public interest themselves.

In the period of the so-called state socialism existing until the end of 1980s, in which the entire administrative regulation was usurped by the state, and selfgovernment, at least in the conditions of the then Czechoslovakia, was suppressed, one basically could not speak about self-government. Local administration was

\footnotetext{
1 J. Hoetzel, Československé správní právo. Část všeobecná, Praha 1934, pp. 158-162.

2 A. Merkl, Obecné právo správní, Praha-Brno 1932, pp. 182-194.

3 E.g., see J. Matějka, Pojem veřejnoprávní korporace, Praha 1929, p. 99.
} 
carried out by national committees built up in essence on the principle of "soviets"; they were exclusively the state bodies identified in the constitution as state authority and administration bodies, ${ }^{4}$ and had no property of their own but performed the management of the state property. Separate organizations for work in professions existed to a very limited extent only; for instance, in the case of the legal profession, lawyers were in labour relationships with the regional associations of lawyers of which they were members, wherein they did not work freelance on their own behalf and account. The regional associations of lawyers, as well as the Central Office of Czech Lawyers, were the then forms of legal entities (in legislation, they were identified as "socialist organizations"). ${ }^{5}$

After the changes in the state structure and return to the values of a legal and democratic state after the year 1989, the former existence of the public self-governance of interest groups was reconstituted only partially. The activities of trade associations were not renewed in such a form which would continue the system of guilds as public corporations involving persons operating the same or related trades in the same or neighbouring municipalities. ${ }^{6}$ Although Trade Licensing Act No. 455/1991 Sb. allowed for the option to establish trade societies as private legal entities; associations per Act No. 83/1990 Sb., on the right of association, such trade societies were not authorized to decide on the issues concerning the groups of persons who could run such trades and on the trade running standards, which is why this institute did not come into its own. A later amendment of Trade Licensing Act No. 167/2004 Sb. then omitted the term of trade societies from the Trade Licensing Act completely.

Since 1990, however, more professional chambers have been established as public corporations of self-governing interest groups, to which the law gave the authority to decide on the legal matters of running such professions. The first chambers were the Czech Bar Association, established through Act No. 128/1990 $\mathrm{Sb}$., for the legal profession, and the Chamber of Commercial Lawyers of the Czech Republic, established through Act No. 209/1990 Sb., for commercial lawyers and the legal assistance provided by them.

\section{Professional Self-Governance}

12 professional chambers have been established in the Czech Republic before now. These are listed below:

${ }^{4}$ Art 86(1) of Constitutional Act No. 100/1960 Sb., the Constitution of the Czechoslovak Socialist Republic.

5 See in particular Sections 16-18, 31 and 43 of Act No. 116/1975 Sb., on the legal profession.

6 S. 106 of Imperial Patent No. 227/1859 ř. z., the trade regulations. Out of the period literature, see e.g. A. Ottis, Naše živnostenské právo, Praha 1947, p. 222 et seq. 
The Czech Bar Association, established through Act No. 128/1990 Sb., for the legal profession, which operates public administration in the legal profession (cf. Section 40(3)). The Czech Bar Association is the largest self-governing legal profession/organization in the Czech Republic. ${ }^{7}$

The Czech Chamber of Architects and the Czech Chamber of Chartered Engineers and Technicians Engaged in Construction, both established through Act No. 360/1992 Sb. The Czech Chamber of Architects unites all chartered architects as regular members, while the Czech Chamber of Chartered Engineers and Technicians Engaged in Construction associates all chartered engineers and technicians engaged in construction as regular members (cf. S. 23(2)).

The Chamber of Distrainers of the Czech Republic, which is the self-governing body of all distrainers, was established through Act No. 120/2001 Sb. Among other things, it supervises the distrainers' activities and the activities of the distrainer's office (cf. S. 7(5)).

The Chamber of Auditors of the Czech Republic, which is the self-governing organization of all auditors, monitoring, for instance, whether auditors and assistance auditors observe the provisions of Act No. 93/2009 Sb., through which the Chamber was established [cf. S. 31(1)(2b)].

The Chamber of Tax Advisers of the Czech Republic, which was established through Act No. 523/1992 Sb. and which unites all tax advisers [cf. S. 9(2a)].

The Chamber of Patent Attorneys of the Czech Republic, established through Act No. 417/2004 Sb., is a self-governing professional association of all patent attorneys (cf. S. 3(2)).

The Chamber of Veterinary Surgeons of the Czech Republic, which is the self-governing professional organization uniting veterinary surgeons. The Chamber was established through Act No. 381/1991 Sb. and, among other things, it makes sure that its members perform their vocation in a professional way and in compliance with its ethics [cf. S 1 and S. 2(1a)].

The Notarial Chamber of the Czech Republic, which was established through Act No. 358/1992 Sb. and which is formed by separate notarial chambers associating all notaries public with offices within the particular districts (cf. S. 29(4) and S. 35).

The Czech Chamber of Pharmacists, the Czech Medical Chamber and the Czech Dental Chamber, which were established through Act No. 220/1991 Sb. These chambers are self-governing non-political professional organizations bringing together all doctors, dentists and pharmacists entered in the lists kept by the chambers (cf. S. 1(2")).

All the aforementioned chambers are based on the principle of compulsory membership. The issue of compulsory membership was relatively extensively investigated by the Constitutional Court which, in its verdict of 16 April 2003, File

\footnotetext{
${ }^{7}$ Cf. www.cak.cz.
} 
No. I. ÚS 181/01, formulated a conclusion in context with the profession of a veterinary surgeon, which can be applied in general to all the above-mentioned professional chambers as public corporations. As the Constitutional Court stated, the self-governing interest groups, in particular the professional chambers with compulsory membership, unite self-employed natural persons in certain professions in which there is a strong public interest in their due performance. Such chambers are legal entities of the public law, being established by law and equipped with the authority to issue various internal regulations for the chamber and its members, who must abide by them with respect to their compulsory membership. Thus, the chamber executes certain power authorities over its members as subjects to a certain professional status. The said authorities typically include a disciplinary power. To the issue of compulsory membership as obiter dictum, the Constitutional Court then added that "everyone who wants to run his or her profession in the prescribed manner must be a member of the chamber by law. The Constitutional Court also concluded that the provision of Section 4(1) of Act No. 381/1991 Sb., which stipulates that a veterinary surgeon who performs veterinary treatment and preventive activities in the territory of the Czech Republic must be a member of the Chamber, with the exception of a visiting veterinary surgeon, perhaps could not be formulated more clearly. As already suggested above, it is a profession which holds a great public interest in its top-quality performance (similar to the due performance of lawyers, notaries public, doctors, pharmacists, patent attorneys, and so on), which is why the Chamber has been assigned certain authoritative powers to be able to guarantee compliance with this requirement. ${ }^{8}$

The Constitutional Court also studied the issue of compulsory membership in relation to membership in the Czech Medical Chamber, namely in its verdict of 14th October 2008, File No. Pl. ÚS 40/06-2, in which the Constitutional Court concluded that compulsory membership was not in contradiction with the constitutional order, especially with Article 20 (and Art. 27 Para. 1 and 2) of the Charter. The authors of this essay identify themselves with the above-mentioned conclusions of the Constitutional Court, as it can be stated that compulsory membership in professional chambers is undoubtedly requisite, especially regarding the assurance of the proficiency of their members, certain standards to be achieved in the services they provide, consistent surveillance over their performance in these professions, and execution of the disciplinary authority associated therewith.

The professional chamber laws stipulate the right of persons who apply for membership in the chambers, providing they meet the set conditions, to be admitted to the chambers and to be entered in the relevant list of persons performing the respective profession. As the first laws governing professional chambers were passed at the time, there still was no special administrative judicial system established, a form of judicial protection of persons who had applied for being admitted to

8 The verdict of the Constitutional Court of 16 April 2003, File No. I. ÚS 181/01. 
a chamber unsuccessfully was set up in the civil judicial system, allowing them to file an action against the chamber for imposing an obligation upon it to make an entry in the list kept by the chamber. ${ }^{9}$ On the basis of a change in the case law arrived at by a special senate established per Act No. 131/2002 Sb., on decision making in some competence disputes, however, protection against the refusal of a request for entry in a chamber or against inactivity of the chamber consisting of not entering an applicant in the list is provided in the administrative judicial system per the provisions of Act No. 150/2002 Sb., the Code of Administrative Justice. ${ }^{10}$

The Notarial Chamber of the CR and the Chamber of Distrainers of the CR use the rule of a limited number of their members (numerus clausus), so these professional chambers organize selection procedures for released positions of notaries public or court-appointed distrainers and propose that the Minister of Justice appoint the selected candidates as notaries public or court-appointed distrainers and to assign them to notary public or distrainer's offices within the jurisdiction of district courts.

As a rule, the self-governance executed by the professional chambers covers the following issues:

- Decisions on the admission of persons performing the profession to be chamber members.

- Checking for observance of the due profession performance obligation by the chamber members.

- Decisions on the rights and obligations of the chamber members in connection with their performance of the professions and in disciplinary procedures for violating the rules of conduct.

- Determination of some issues of internal organization of the chamber (within the bases stipulated by law).

- Definition of more detailed rules of conduct in profession performance in the form of autonomous regulations.

Where the professional chamber bodies decide on the rights and obligations of persons in connection with their membership in the chamber, they act as bodies having a public authority. It does not concern state administration execution, but the other type of public administration: self-governance. In such cases, the professional chamber bodies can be classified within the term "administration body", pursuant to Section 1(1) of Act No. 500/2004 Sb., the Code of Administrative Procedure.

The decisions issued by the professional chamber bodies in administrative proceedings cannot be reviewed through appeals or other regular remedial instruments by a state's body or an administrative authority. ${ }^{11}$ In essence, such deci-

\footnotetext{
${ }^{9}$ See, for instance, S. 8 of Act No. 128/1990 Sb., on the legal profession.

${ }^{10}$ Cf. the verdict of the special senate of 1 August 2017, Ref. No. Konf 28/2014-55.

11 The term "administrative authority" used in Art. 79(1) of Constitutional Act No. 1/1993 Sb., the Constitution of the Czech Republic, corresponds with the term "state administration body" used
} in the past. 
sions come to legal force already within the proceedings before the self-governing corporation body and/or after the remedial instrument procedure conducted by another self-governing corporation body. ${ }^{12}$ If it concerns decisions which could infringe upon the subjective public rights, they can be appealed against by any person who claims such infringement as a plaintiff, seeking protection for his or her rights in the administrative judicial system through an action against such a decision, per Section 65 et seq. of the Code of Administrative Justice under the conditions set up therein.

The provisions of disciplinary procedures against court-appointed distrainers represent a significant variation from those of other chambers. Authority to hold a disciplinary procedure against professional chamber members (and articled clerks, probationers or otherwise designated persons preparing for being admitted as members) belongs to the chamber bodies. This was originally also the case of court-appointed distrainers, where the authority to conduct disciplinary proceedings against them belonged to the disciplinary board of the Chamber of Distrainers. ${ }^{13}$ Through an amendment - Act No. 286/2009 Sb. - however, the authority to conduct disciplinary proceedings against court-appointed distrainers was entrusted to a disciplinary court, which is the Supreme Administrative Court. ${ }^{14}$ The grounds of this otherwise non-systematic measure were some unconvincing procedures taken by the then Chamber of Distrainers bodies against some of its members who had clearly violated their professional obligations, but the Chamber of Distrainers bodies failed to draw disciplinary conclusions against them.

\section{Losses caused through the execution of professional self-government}

Through their procedures in the performance of their administrative activities, namely by decision-making, but also by unlawful inactivity, the professional chamber bodies can cause losses by course of the civil law to persons concerned in such procedures, especially the professional chamber members. A situation may occur where a professional chamber member - a lawyer, for instance - has the performance of his or her activity suspended, so that he or she cannot perform these activities for a certain period of time under the decision of a chamber body, but the activity suspension decision is proved later to be, in fact, unlawful and

12 Cf., for instance, S. 35, S. 55(5) of Act No. 85/1996 Sb., on the legal profession.

13 See S. 117 of Act No. 120/2001 Sb., on court-appointed distrainers and distraining activities (Code of Distraint Procedure), in the wording effective until 31.10.2009.

14 See Act No. 7/2002 Sb., on proceedings in the matters of judges, prosecutors and courtappointed distrainers, namely Sections 1 and 3 . 
unsubstantiated. It is the deficiency of the Czech legislation that it fails to address compensations for such damages at the legal level as losses caused through professional self-government execution.

The constitutional grounds of liability for losses caused by public authority execution are formed by the Charter of Fundamental Rights and Freedoms, ${ }^{15}$ which laid down in Art. 36(3) the fundamental right of individuals to claim damages incurred by an unlawful decision or incorrect official procedure: "Everybody is entitled to compensation for damages caused to him or her by an unlawful decision of a court, other organs of the State or public administration, or through wrong official procedure." According to Art. 36(4) of the Charter, "the conditions and detailed provisions in this respect shall be set by law". For the first time in the Czech or Czechoslovak history, the right to claim damages caused by a public authority was laid down as a constitutional right and, therefore, one can conclude that this fundamental right has been constituted as a right of an individual towards the state. And the practicability of this right should not be restricted for the sole reason that, in some cases, the public authority enforced against an individual is assignable to other subjects than the state.

The problem was that the laying down of the constitutional right in Art. 36(3) of the Charter was not followed by adopting such a legislative provision which would deal with liability for a loss caused by exercising the public authority in its plurality, i.e., not only when it concerned an activity of or attributable to the state.

Act No. 82/1998 Sb., on liability for losses caused through decisions or wrong official procedures in exercises of public authority (the "Liability Act"), passed later, deals with the liability of not only the state, but also of territorial self-governing units for losses caused in executing public authority and, since the amendment made through Act No. 160/2006 Sb., it also regulates the obligation of the state and of the territorial self-governing units to compensate for non-material damages incurred. ${ }^{16}$ Per Section $\S 26$ of the Liability Act, there is the principle of the subsidiarity of the Civil Code: "Unless otherwise is stated, the legal relations regulated by this law are governed by the Civil Code."

The Liability Act, however, neglected the issue of the liability of other public administration subjects for losses caused when executing the public authority assigned to them. This is neither addressed by the general law on liability for losses — the Civil Code (Act No. 89/2012 Sb.) — which neither within the regulations on obligations from torts (Book 4, Title II), nor in any other place contains provisions on conditions of liability for losses caused by executing the public authority;

15 The Charter was implemented through the Constitutional Act of the Federal Assembly of the Czech and Slovak Federative Republic No. 23/1991 Sb., per Art. 112(1) of later Constitutional Act No. 1/1993 Sb., the Constitution of the Czech Republic, it forms a part of the constitutional order of the Czech Republic, and it was re-entered in the Collection of Laws of the Czech Republic under No. 2/1993 Sb.

${ }^{16}$ Cf. S. 1(1, 2 and 3) of the Liability Act. 
the Civil Code kept the validity of the current special regulations of the Liability Act, as well as other special regulations dealing with liability for losses caused by executing the public authority.

For comparison, Slovak Act No. 514/2003 Z.z., on liability for losses caused by public authority execution, ${ }^{17}$ includes bodies of self-governing interest groups among the public authority bodies [S. 2(b)(2)], with the state then being liable for any losses caused in the execution of the public authority by, inter alia, also the bodies of self-governing interest groups (cf. S. 3(1)), while the "self-governing interest group" acts in cases caused by its body as a public authority body in the settlement of damages on behalf of the state [cf. S. 4(1)(i)].

\section{Is exercise of public authority by professional chambers considered to be an execution of state administration?}

As for the professional chambers, there were more verdicts of Czech courts published which concluded, incorrectly in our opinion, that professional chambers perform state administration within the scope set by law.

For instance, according to the judgement of the Court of Appeal in Prague from 22nd December 1995, File No. 7 A 83/94, ${ }^{18}$ it follows from the listing of functions and authorizations and from the scope of operation of the Czech Chamber of Pharmacists laid down in Act No. 220/1991 Sb., on the Czech Medical Chamber, the Czech Dental Chamber and the Czech Chamber of Pharmacists, as a self-governing non-political professional organization which associates all pharmacists entered in the list kept by the chamber (S. 1(2) of the above-cited law) that the chamber is a self-governing public corporation to which the execution of state administration was transferred within the scope set by law; the competence in the public administration area has a basis in the compulsory membership laid down in the provisions of Section 3(3) of the above-cited law, according to which a graduate from a higher education studying in the branch of pharmacy, who performs his or her vocation in a pharmacological facility in the CR, must be member of this chamber. The chamber is entitled, among other things, to define conditions for running a private practice by its members and for their work as professional representatives per a special regulation, and is entitled to issue certificates to confirm the fulfilment of the conditions specified for the performance of these

17 This Act cancelled, among other things, previous Czechoslovak (Federal) Act No. 58/1969 $\mathrm{Sb}$, , on liability for losses caused by decision or incorrect official procedure, for the territory of Slovakia.

18 Judicial case law in administrative matters, 1998, No. 5, Decision No. 222. 
activities. According to the court, "[in] this case, i.e., when issuing a decision on the fulfilment of the conditions for running a private practice by its members and to work as professional representatives per a special regulation, the chamber executes state administration transferred to it by law, i.e., issues an authoritative decision of a public nature."

In its judgement of 7th November 2003, File No. 51 Co 304/2003, which concerned the issue of liability for a loss caused by the Czech Chamber of Pharmacists by not issuing a certificate for work as a professional representative, the Municipal Court in Prague expressed its opinion that the chamber executes the state administration transferred to it, and if a loss occurred in the execution of the state administration transferred to the chamber, liability would be borne by the state, not the chamber. A legal sentence was published, stating that "the state is liable for a loss caused by an incorrect decision or an improper procedure of the Czech Chamber of Pharmacists in executing state administration transferred to the Czech Chamber of Pharmacists through Act No. 220/1991 Sb., as amended."19

In its judgement of $16^{\text {th }}$ November 2015, File No. 30 Cdo 1711/2015, the Supreme Court of the Czech Republic dealt with the issue of whether disciplinary proceedings held by the Czech Bar Association against a lawyer under the act on the legal profession are deemed to be of public authority and able to establish the state's liability for a loss, per the Liability Act. The Court concluded that disciplinary proceedings held by the Czech Bar Association against a lawyer are deemed to be execution of public authority. The conclusion that disciplinary proceedings held to deal with a disciplinary offence as a type of tort constituted by the act on the legal profession, is of a public-law nature and concerns public authority execution, is not and probably never was questioned in any way and corresponds to the concept that self-governing corporations are entitled to perform certain public administration. This, for that matter, is also stated by the act on the legal profession itself, according to which the Czech Bar Association is a "self-governing professional organization of all lawyers" (S. 40(2)), a legal entity (S. 40(4)) which "executes public administration in the legal profession" (S. 40(3)). As follows from the last sentence, public administration in the legal profession is not executed by, for instance, state bodies - administrative authorities (the direct executors of state administration). In the above-cited judgement, however, the Supreme Court concluded ipso facto that it concerned "the execution of entrusted state administration".

But the opinions of the above-cited judgement of the Supreme Court of the Czech Republic were superseded by the Constitutional Court of the Czech Republic in its verdict of $28^{\text {th }}$ February 2017 , File No. IV. ÚS 3638/15, in which it opined that the state was not liable for losses caused in executing public authority by professional chamber bodies (namely, the bodies of the Czech Bar Association in disciplinary proceedings held against a lawyer) and stated that, in such cases, the professional chamber itself would be liable for such a loss. Crucially, it can

19 Judicial case law in administrative matters, 2005, No. 6, Decision No. 86. 
be considered part of the justification in this verdict of the Constitutional Court in which it deals with the nature of the public authority executed by professional chambers. The Constitutional Court noted the differences between the wider term "public authority" and the narrower term "state authority," and also the differences between the subject matter of the terms "state administration" and "public administration": "the execution of state administration was not delegated to professional self-governing corporations (delegated competence); they only execute the authorities and competencies delegated to them within the (decentralized) professional self-government."

The Constitutional Court confirmed the opinion that those acts of professional chambers which are considered to be the execution of public authority are the manifestation of decentralized public administration, different from state administration.

This, however, brought about a paradoxical situation, in that there was no legislative provision of liability for losses caused by the execution of that public authority which was entrusted to the self-governance of professional chambers.

Any loss caused by the execution of public authority occurs from a public law relationship, not from a relationship defined in Section 1(1) of the Civil Code, i.e., under private law. ${ }^{20}$ Such a loss is not incurred in the case of professional chambers by a professional chamber acting as a legal entity, but by the acting of its body, to which execution of a part of public authority has been delegated by law. The Liability Act does not deal with the issue of liability for losses caused by professional chamber bodies; neither is this addressed by the laws through which the individual professional chambers were established nor by other laws. But it is problematic to follow, ipso facto, from the general provisions on liability for losses stipulated in the Civil Code about reimbursement for a material and non-material harm, for other than private-legal grounds of loss occurrence. Any loss caused by an executing public authority is not one caused by a person in the sense of private law, but by an authority delegated by law; by a public authority executor subject to the limits of the state authority per Art. 2(3) of the Constitution or Art. 2(2) of the Charter, which stipulates that state (and also other public) authority can only be executed on the grounds, within the limits of and in the manner imposed by law.

\section{Statutory regulations of professional self-government}

The significant manifestation of self-governance, including the self-governance of interest groups, consists of the issue of their own abstract acts designated in theory as statutory regulations, autonomous self-government regulations, etc.;

${ }^{20}$ Cf., for instance, the verdict of the Constitutional Court of the Czech Republic of 28.08.2007, File No. IV. ÚS 642/05. 
their designation is not uniform even in the legislation. The Czech laws on professional chambers use different designations for the abstract acts issued by the chambers, such as "professional regulations" (the act on the legal profession, the act on the Chamber of Veterinary Surgeons, the Code of Distraint Procedure), "internal regulations" (the act on the profession of chartered architects, the act on auditors), "profession regulations" (the act on patent attorneys), "chamber regulations" (the Notarial Code) or "rules" (the act on the Czech Medical Chamber, the Czech Dental Chamber and the Czech Chamber of Pharmacists; also the act on the Chamber of Veterinary Surgeons, but it also mentions that there also are other professional regulations in addition to the codes). In relation to the issue and contents of the statutory regulations, there also are considerable options for the state's supervision over the professional self-governance executed by the competent ministries.

Although the provisions concerning the issue of statutory regulations differ markedly in the acts on the individual professional chambers, there is an opinion prevailing saying that they are neither legal regulations nor sources of law as they lack general obligatoriness. ${ }^{21}$ An interesting fact is that quite opposite opinions occurred, claiming that they were legal regulations; however, without any further reasoning (while using the generally applicable rule: "When two lawyers meet, they share at least three legal opinions"). The judgement of the Regional Court of Ostrava of 7th December 2015, Ref. No. 65 A 30/2015-53, for instance, stated in relation to the disciplinary code issued by the Czech Chamber of Pharmacists that it was a "sub-statutory legal regulation issued under Act No. 220/1991 Sb." In its judgement of 15th August 2012, Ref. No. 3 Ads 29/2012-23, the Supreme Administrative Court stated in relation to the disciplinary code of the Czech Chamber of Pharmacists that "the disciplinary authority of the Czech Chamber of Pharmacists as it is regulated by the legal regulations, whether the statutory or the internal chamber ones..."; i.e., that there are some statutory legal and "internal chamber" legal regulations.

One can distinguish between statutory regulations whose issue is envisaged expressly by law and other statutory regulations through which a chamber regulates its internal affairs. In the case of the statutory regulations of the first group there is a legal ground or legal authority for their issue; they often are statutory regulations whose issue is envisaged by law as obligatory and which are indispensable for the operation of the professional chamber. Where such statutory regulations impose obligations upon persons, the condition of legal ground is applied to their issue, as follows from Art. 2(3) of the Constitution of the Czech Republic (literally: "State authority is to serve all citizens and may be asserted only in cases, within the bounds, and in the manner provided for by law"; but the term

21 Cf. M. Kopecký, Správní právo. Obecná část, Praha 2021, p. 127. D. Hendrych et al., Správni právo. Obecná ćást, Praha 2016, pp. 129 and 475; V. Sládeček, Obecné správní právo, Praha 2019, p. 69. 
"state authority" is interpreted in a wider context as a public ordering authority). The issue of the statutory regulations of the second group is the matter of intentions of the relevant chamber implemented within the limits of its competences in the internal management relationships.

The law should define cases of such statutory regulations which may bind their addressees legally. The statutory regulations issued by professional chambers bind their members but, in dependence on the legal provisions on the authority to issue them, they can also bind other persons, especially those who are in candidate positions (articled clerks, etc.), preparing for membership in the chamber or those who enter into a legal relationship with the chamber on the basis of their will, e.g., applicants for taking professional examinations.

In some cases, the laws condition the creation or validity of a chamber statutory regulation by an act of the administrative authority supervising the professional chamber:

- Consent from the Ministry of Justice is needed for some regulations of the Notarial Chamber of the Czech Republic to become valid. ${ }^{22}$

- Consent from the Ministry of Justice is needed for the code of office, disciplinary code and code of examination of the Chamber of Distrainers of the Czech Republic to become valid. ${ }^{23}$

- The minister of regional development approves the authorization rules of the Czech Chamber of Architects and the Czech Chamber of Chartered Engineers and Technicians Engaged in Construction. ${ }^{24}$

Granting consent with approval of a chamber's statutory regulation by the competent administrative authority is decided on in administrative proceedings; a legitimate reason for refusal of chamber's application for granting consent or approval would be a contradiction of the chamber's regulation with the law, other legal regulation or an international treaty. The chamber could defend itself against a refusal to grant consent, after potential appeal proceedings, in administrative legal proceedings.

Some laws, as a rule, impose upon chambers the duty to submit statutory regulations after being adopted to the central administrative authority which performs supervision over the chamber, such as:

- The Czech Bar Association is required to submit all professional regulations passed by its bodies to the Ministry of Justice within 30 days. ${ }^{25}$

- The same applies to the Chamber of Distrainers (which submits them to the Ministry of Justice); moreover, for some chamber's regulations to become valid, they require the consent of the Ministry of Justice. ${ }^{26}$

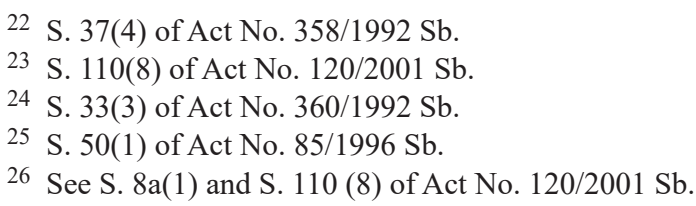


- The Chamber of Auditors discusses motions for amendments in internal regulations or for new internal regulations with the Public Audit Oversight Board and is required to submit to this Board, internal regulations of the chamber, the Code of Ethics and auditor standards within 30 days of their approval by the assembly. The Public Audit Oversight Board is a legal entity founded by the act on auditors and, therefore, is not a state body.

It is interesting that the statutory regulations adopted by "medical chambers" do not need any approval or oversight by a central state body; Act No. 220/1991 Sb. does not stipulate any authority of the Ministry of Health or other administrative body. This fact is also undoubtedly a sign of the strong position of these chambers, founded already at the beginning of renewal of the professional self-governance, when the legislature did not intend to subordinate these chambers to state supervision, as is the case in other chambers.

The activities of professional chambers are not put beyond the law; therefore, in terms of protection of the public interests and of the subjective rights of the persons in the legal situations in which the statutory regulations of the chambers intervene, the possibility of judicial control is crucial.

With respect to the judicial protection of the subjective rights of individuals (mainly the chamber members), there is especially the incidental control of the chamber regulations as basis for the issue of an administrative decision within action proceedings against an administrative body's decision. For instance, it can occur in action proceedings against a decision on a disciplinary tort consisting in violation of a chamber's statutory regulation.

A statutory regulation is not an administrative body decision pursuant to Section 65(1) of the Code of Administrative Justice and, therefore, no action can be filed against it for protection of the subjective public rights as against a decision. Theoretically, one cannot exclude the option of defending oneself with action against intervention per Section 82 of the Code of Administrative Justice, providing a chamber's statutory regulation has infringed upon the individual's rights. The judicial protection of the subjective rights of an individual affected directly or as a result of an unlawful statutory regulation obviously does not require any special process arrangement, as one can use the current provisions of the Code of Administrative Justice or other laws.

But a different situation occurs in terms of options of judicial protection against unlawful statutory regulations of professional chamber in view of public interest. Neither the Code of Administrative Justice nor any other law regulate the process procedure as to how discussing a motion for cancellation of such regulations by a court could generally be initiated. If they are not legal regulations, one cannot use the provisions on Constitutional Court decision-making on motions for cancellation of other legal regulations or their individual provisions.

In some cases only, the laws on professional chambers stipulate the authority of the minister who heads the ministry oversighting the activities of the particular 
chamber to file a motion to review a chamber's statutory regulation by a court, without however stating by which court and according to which process provision such motion should be decided. For instance, according to the act on the legal profession, if the minister of justice believes that a professional regulation of the Czech Bar Association is in contradiction with the law, he is entitled to file a motion for reviewing it by a court, ${ }^{27}$ but the law does not note according to which process rules the court should proceed in this case.

Attention should be paid to the option to commence judicial proceedings concerning cancellation of a chamber's regulation stipulated in the act on patent attorneys. If the chair of the Industrial Property Office believes that a professional regulation of the Chamber of Patent Attorneys is in contradiction to an EU law or regulation, he is entitled to file an action with the competent court within two months of its adoption. According to the above-cited law, "such proceedings are held accordingly to the provisions on filing an action against an administrative body's decision". Thus, the act on patent attorneys is the only (!) law which stipulates according to what process provisions the court should proceed in dealing with a motion for cancellation of a statutory regulation of the chamber, while such a provision is missing in the regulations of other chambers.

\section{Conclusion}

The self-governing activities performed by the public corporations undoubtedly has its place within a democratic state. It is important, then, for not only the territorial self-governance executed by self-governing units (municipalities and regions in the Czech Republic), but also so-called self-governance of interest groups represented mainly by professional chambers which are entitled by law to decide on the legal matters concerning the execution of their respective professions.

The professional chambers doing their business in the Czech Republic are founded on the principle of compulsory membership. Therefore, if a natural person wishes to carry out the profession in question associated with the particular professional chamber, such person must become a member of the professional chamber and must meet the conditions set for admission to it. The above-mentioned requirement follows especially from the fact that there is a high public interest in the due performance of such activities, and, in response to it, the respective chambers are equipped with authorizations they need to guarantee meeting the requirement.

In connection with the execution of professional self-governance, such situations may occur in which the professional chamber bodies cause losses to their

27 S. 50(2) of Act No. 85/1996 Sb. 
members. Although the Czech legislation does not deal with the issue of compensation for damages caused by professional self-governance execution at the legal level, answering the issue cannot be neglected. In compliance with Art. 36(3) and (4) of the Charter, it is undoubtedly desirable that this issue be regulated by law, similarly to, for instance, Slovakia through Act No. 514/2003 Z.Z., on liability for losses caused by public authority execution.

Another gap in the Czech legislation can be found in respect to the statutory regulations of the professional chambers where, with the exception of the act on patent attorneys, the legal order does not regulate the issue of judicial protection from unlawful statutory regulations of the professional chambers as regards the public interest. Even if some laws on professional chambers envisage the option of judicial review of a professional chamber's statutory regulation, they fail to stipulate further according to which process rules and legal provisions the court should proceed.

Thus, although the legal provisions on the self-governing activities of the professional chamber in the Czech Republic can be considered to be more or less appropriate, it is necessary in respect of the legal safeguard and assurance of sufficient protection of the rights of the involved persons (chamber members) to rectify the above-mentioned shortcomings in the Czech legal order.

\section{Bibliography}

Hendrych D. et al., Správní právo. Obecná část, Praha 2016.

Hoetzel J., Československé správní právo. Část všeobecná, Praha 1934.

Kopecký M., Správní právo. Obecná část, Praha 2021.

Matějka J., Pojem veřejnoprávni korporace, Praha 1929.

Merkl A., Obecné právo správní, Praha-Brno 1932.

Ottis A., Naše živnostenské právo, Praha 1947.

Sládeček V., Obecné správní právo, Praha 2019.

Prawo 333, 2021

(C) for this edition by CNS 